\title{
Panduan Praktikum Biokimia II Berbasis Inkuiri Terbimbing dengan Pendekatan Kearifan Lokal
}

\author{
Oktri Anggo $^{1}$, Endang Budiasih ${ }^{1}$, Siti Marfu'ah ${ }^{1}$ \\ ${ }^{1}$ Pendidikan Kimia-Universitas Negeri Malang
}

\section{INFO ARTIKEL}

\section{Riwayat Artikel:}

Diterima: 21-03-2019

Disetujui: 19-07-2019

Kata kunci:
guided inquiry;
local culture;
biochemistry
inkuiri terbimbing;
kearifan lokal;
biokimia

\section{Alamat Korespondensi:}

\section{Oktri Anggo}

Pendidikan Kimia

Universitas Negeri Malang

Jalan Semarang 5 Malang

E-mail: oanggooo@gmail.com

\begin{abstract}
ABSTRAK
Abstract: This research aims to develop biochemical practicum guidelines II and test the guidelines for small-scale practicum guides. This research was developed based on the Thiagarajan (4D) method. The practicum guide produced is a biochemistry practical guide II specifically for students, biochemical practicum guide II specifically for lecturers /assistants and multiple choice tests. The validation guide shows guidelines for biochemical practices specifically students have an average value of 88.89 with very feasible criteria and biochemical practicum guidance guide II specifically for lecturers / assistants has an average value of 91.11 with very feasible suggestions. The results of a small group biochemical practicum guide for students specifically had an average score of 85.94 with very decent criteria. This shows that the practicum guide for the results of the development is feasible to be used in biochemistry practicum II lectures.

Abstrak: Penelitian ini bertujuan untuk mengembangkan panduan praktikum biokimia II dan uji kelompok kecil panduan praktikum hasil pengembangan. Penelitian ini dikembangkan menurut metode Thiagarajan (4D). Panduan praktikum yang dihasilkan yaitu panduan praktikum biokimia II khusus mahasiswa, panduan praktikum biokimia II khusus dosen/asisten dan tes pilihan ganda. Hasil validasi ahli menunjukan bahwa panduan praktikum biokimia khusus mahasiswa memiliki rata-rata nilai 88,89 dengan kriteria sangat layak dan panduan panduan praktikum biokimia II khusus dosen/asisten memiliki rata-rata nilai 91,11 dengan kriteria sangat layak. Hasil uji coba kelompok kecil panduan praktikum biokimia II khusus mahasiswa memiliki rata-rata nilai 85,94 dengan kriteria sangat layak. Hal ini menunjukan bahwa panduan praktikum hasil pengembangan layak untuk digunakan pada perkuliahan praktikum biokimia II.
\end{abstract}

Penerapan kurikulum terintegrasi berdampak pada perubahan pada beberapa matakuliah. Salah satu matakuliah yang mengalami perubahan yaitu matakuliah biokimia II. Perubahan dapat dilihat dari penyatuan Satuan Kredit Semester antara teori dan praktikum. Sebelum diterapkan kurikulum terintegrasi terdapat pemisahan antara matakuliah biokimia II dan praktikum biokimia II. Konsep integrasi pada dasarnya mengacuh pada kesatuan, keutuhan, kecukupan, kerumitan yang ditunjukkan dengan hubungan dan kaitan antara komponen-komponennya (Sa'ud, 2008). Susunan kurikulum secara terintegrasi merupakan sebuah kurikulum yang menghapuskan penyekat antar matakuliah dan menyuguhkan bahan studi dalam bentuk utuh.

Kurikulum terintegrasi adalah kurikulum yang mengharuskan mahasiswa baik selaku perseorangan maupun secara bersama berperan mengeksplorasi, menemukan ide, hakikat secara keseluruhan bermanfaat dan faktual. Melalui pertimbangan itu, pembelajaran terintegrasi memfokuskan pada penyampaian pembelajaran yang substansial dengan melibatkan mahasiswa dalam sistem pengkajian. Melalui proses terintegrasi juga mahasiswa mampu memperoleh ilmu secara utuh dengan cara menghubungkan antar aspek bidang ilmu. Kurikulum terintegrasi juga diterapkan pada program studi pendidikan kimia FKIP Universitas Riau yang bertujuan menjadi pusat penelitian dan pengembangan pendidikan kimia, serta mampu menghasilkan tamatan yang bermutu dan berguna untuk masyarakat Riau pada khususnya dan Indonesia pada umumnya pada tahun 2020 (Tim Penyusun Kurikulum Program Studi Pendidikan Kimia, 2014).

Berdasarkan uraian kurikulum dan fakta penting yang ditemui pada praktikum biokimia II di program sudi pendidikan kimia FKIP UR, perlu dilakukan pengembangan panduan praktikum yang memiliki karakteristik sebagai berikut. Pertama, pengembangan panduan praktikum yang bermakna dan dapat mengonstruk pengetahuan mahasiswa. Kedua, diperlukan model pembelajaran yang tepat untuk pengembangan panduan praktikum. Ketiga, pengembangan panduan praktikum yang disesuaikan dengan keadaan laboratorium. Keempat, pengembangan panduan praktikum yang memanfaatkan bahan yang bersumber kearifan lokal dari Riau. Solusi yang memungkinkan untuk mengatasi permasalahan tersebut adalah perlunya dilakukan pengembangan 
panduan praktikum biokimia II berbasis inkuiri terbimbing dengan pendekatan kearifan lokal Riau. Model pembelajaran inkuiri terbimbing dengan pendekatan kearifan lokal Riau merupakan salah satu inovasi dalam perkuliahan program studi pendidikan kimia FKIP UR dapat membuat perkuliahan praktikum biokimia II menjadi lebih bermakna dan mewujudkan penerapan kurikulum terintegrasi.

Menurut (Arends, 2012), pengetahuan yang diperoleh melalui lingkungan di sekitarnya merupakan dasar dari teori konstruktivistik yang di kemukakan oleh (Piaget \& Duckworth, 1970). Teori konstruktivistik merupakan dasar pemikiran dari pembelajaran pendekatan inkuiri terbimbing. Menurut (Prince \& Felder, 2006), inkuiri terbimbing adalah suatu model pembelajaran yang diawali dari permasalahan-permasalahan khusus yang bertujuan untuk membangun konsep. Penelitian ini mengadopsi tahapan inkuiri terbimbing menurut (Qing, dkk., 2010). Proses pembelajaran kimia yang tidak mengarah terhadap pembangunan suatu kelompok dinilai kurang bermakna. (Suastra, 2010) menyebutkan bahwa pembelajaran sains saat ini mengabaikan aspek-aspek yang digunakan oleh suatu kelompok asli yang penuh dengan nilai kearifan lokal. Menurut (Merdekawati, 2012), local genius merupakan suatu kecendekiaan masyarakat sekitar dalam memfilter pengaruh budaya luar dan budaya asli sehingga membentuk wujud baru yang lebih baik, indah, selaras dengan situasi lingkungan setempat dan menjadi jati diri daerah tersebut. Integrasi kearifan lokal di dalam pendidikan kimia dapat diwujudkan dengan pembelajaran IPA (Syaban \& Wilujeng, 2016). Penelitian serupa juga dilakukan oleh (Tampubolon, 2015) yang mengembangkan perangkat unsur-unsur kimia dengan pendekatan kearifan lokal.

Berdasarkan uraian tersebut perlu dikembangkan bahan ajar berupa panduan praktikum biokimia II dengan pendekatan kearifan lokal. Panduan praktikum sangat diperlukan untuk menunjang keberhasilan dalam proses pembelajaran, jika buku panduan praktikum tidak ada maka akan menghambat pelaksanaan praktikum dan menyebabkan proses pembelajaran tidak berlangsung secara optimal (Anggraini, 2016). Kajian terhadap panduan praktikum sebelumnya telah diujicobakan oleh Arifin, dkk., 2015) menyebutkan bahwa panduan praktikum layak dijadikan alat bantu menggali ilmu kimia. Berdasarkan hasil penelitian (Mukhtar, Emiliya, Silaban, 2015; Yani, 2015; Zakiah, Silalahi, \& Muchtar, 2015) bahwa panduan praktikum sangat layak sebagai patokan saat praktikum dan sebagai bahan ajar pendukung.

\section{METODE}

Tahapan yang digunakan dalam pengembangan bahan ajar menurut model 4D (Thiagarajan, 1974), yaitu tahapan pendefenisisan (Define), perancangan (Design), pengembangan (Develop), dan penyebaran (Disseminate). Panduan praktikum biokimia II hasil pengembangan divalidasi oleh tiga validator ahli. Validasi ahli dilakukan untuk memperoleh saran serta penilaian dari validator yang bertujuan untuk mengetahui tingkat kevalidan panduan praktikum yang dikembangkan. Validator memiliki keahlian dalam bidang pendidikan dan biokimia.

Hasil validasi dari validator kemudian melalui tahapan revisi. Setelah melalui tahap revisi panduan praktikum biokimia hasil pengembangan diujicobakan pada kelompok kecil. Uji coba kelompok kecil bertujuan untuk uji keterbacaan panduan praktikum khusus mahasiswa. Uji coba kelompok kecil dilakukan ke pada mahasiswa program studi pendidikan kimia FKIP UR angkatan 2014. Mahasiswa uji coba kelompok kecil dipilih secara acak. Kriteria mahasiswa pada uji coba kelompok kecil adalah mahasiswa yang telah menempuh perkuliahan praktikum biokimia II dan berkemampuan tinggi, sedang, dan rendah. Kriteria kelayakan validasi ahli dan uji coba kelompok kecil dengan menggunakan teknik analisis data persentase (Arikunto, 2012).

\section{HASIL}

Pada tahapan pendefinisian (Define) dilakukan analisis panduan praktikum yang digunakan pada program studi pendidikan kimia FKIP UR. Karakteristik panduan praktikum yang digunakan pada jurusan program studi pendidikan kimia sebagai berikut. Pertama, panduan praktikum yang digunakan tidak mencerminkan kurikulum terintegrasi. Kedua, model pembelajaran yang digunakan adalah verifikasi konsep bukan bersifat penemuan konsep oleh mahasiswa. Ketiga, panduan praktikum kurang mencerminkan analisis senyawa penting dalam hidup dengan menggunakan cara-cara yang lebih sederhana. Keempat, tidak ada uji kualitatif sederhana yang dapat menunjang pengetahuan mahasiswa yang dapat mengaitkan secara langsung antara materi dengan kehidupan sehari-hari. Kelima, tidak memanfaatkan kekayaan alam Riau sebagai sumber belajar.

Pada perancangan (Design) diperoleh rancangan berupa rangka pembuatan panduan praktikum khusus mahasiswa dan panduan praktikum khusus dosen/asisten. Panduan praktikum disusun berdasarkan tahapan inkuiri terbimbing yang diadopsi dari Qing, dkk. (2010) dan pendekatan kearifan lokal Riau. Panduan praktikum dirancang dengan memanfaatkan bahan yang banyak terdapat di sekitar Riau sebagai sampel percobaan praktikum.

Pada tahap pengembangan (Develop) dilakukan penyusunan draf panduan praktikum khusus mahasiswa dan panduan praktikum khusus dosen. Panduan praktikum khusus dosen terdapat silabus, satuan acara perkuliahan, jawaban pertanyaan dan soal ujian akhir serta kisi-kisi jawaban. Sementara itu, pada panduan praktikum khusus mahasiswa tidak terdapat. Tahap berikutnya dilakukan uji validasi yang dilakukan oleh tiga tenaga pengajar yang berkompeten di bidang pendidikan dan materi biokimia. Data lengkap hasil uji validasi panduan praktikum khusus mahasiswa, hasil validasi panduan praktikum khusus dosen dan hasil uji coba kelompok kecil disajikan secara berurutan pada tabel 1, 2, dan 3. 
Tabel 1. Hasil Validasi Panduan Praktikum Biokimia II Khusus Mahasiswa

\begin{tabular}{lccl}
\hline \multicolumn{1}{c}{ Aspek } & Rata-Rata Skor & Persentase & Kriteria Kelayakan \\
\hline Kelayakan isi dan penyajian & 4,28 & 85,58 & Sangat Layak \\
\hline Kebahasaan & 4,42 & 86,67 & Sangat Layak \\
\hline Tata letak & 4,44 & 88,89 & Sangat Layak \\
\hline Rata-Rata & 4,38 & 85,93 & Sangat Layak \\
\hline
\end{tabular}

Tabel 2. Hasil Validasi Panduan Praktikum Biokimia II Khusus Dosen/Asisten

\begin{tabular}{llll}
\hline \multicolumn{1}{c}{ Aspek } & Rata-Rata Skor & Persentase & \multicolumn{1}{c}{ Kriteria Kelayakan } \\
\hline Bagian pengantar & 4,6 & 92 & Sangat Layak \\
\hline Ketepatan isi dan materi & 4,17 & 83,33 & Sangat Layak \\
\hline Silabus & 4,33 & 86,67 & Sangat Layak \\
\hline Satuan acara perkuliahan & 4,56 & 91,11 & Sangat Layak \\
\hline Pedoman penilaian & 4,56 & 91,11 & Sangat Layak \\
\hline Rata-Rata & 4,44 & 88,84 & Sangat Layak \\
\hline
\end{tabular}

Tabel 3. Hasil Uji Coba Kelompok Kecil

\begin{tabular}{llll}
\hline \multicolumn{1}{c}{ Aspek } & Rata-Rata Skor & Persentase & Kriteria \\
\hline Kemenarikan sampul dan keseluruhan bahan ajar & 4,4 & 88 & Sangat Layak \\
\hline Kejelasan identitas bahan ajar & 4,47 & 89,33 & Sangat Layak \\
\hline Kesesuaian urutan bahan ajar & 4,27 & 85,33 & Sangat Layak \\
\hline Kejelasan petunjuk penggunaan bahan ajar & 4 & 80 & Layak \\
\hline Bagian pengantar dapat mempermudah penggunaan panduan praktikum & 4,4 & Sangat Layak \\
\hline Kejelasan gambar/tabel yang disajikan & 4,47 & 88 & Sangat Layak \\
\hline Kejelasaan penggunaan font & 4,2 & 89,33 & Sangat Layak \\
\hline $\begin{array}{l}\text { Kemudahan dalam memahami pertanyan-pertanyaan dari soal-soal } \\
\text { latihan di akhir setiap bahan ajar }\end{array}$ & 4,07 & 81,33 & \multirow{2}{*}{ Sangat Layak } \\
\hline Kejelasan bahasa yang digunakan dalam bahan ajar & 4,53 & 90,67 & Sangat Layak \\
\hline Kesesuaian dengan KBBI & 4,47 & 89,33 & Sangat Layak \\
\hline Kemudahan dalam menggunakan petunjuk & 4 & 80 & Layak \\
\hline Rata-Rata & 4,29 & 85,94 & Sangat Layak \\
\hline
\end{tabular}

\section{PEMBAHASAN}

Panduan praktikum hasil pengembangan menghasilkan dua buku panduan praktikum biokimia II, yaitu buku panduan praktikum khusus mahasiswa dan buku panduan praktikum khusus dosen/asisten. Pada buku panduan praktikum khusus dosen/asisten terdapat silabus, SAP dan kunci jawaban. Panduan praktikum dikembangkan menggunakan pendekatan inkuiri terbimbing dengan pendekatan kearifan lokal Riau. Bahan yang digunakan sebagai sampel merupakan bahan yang banyak dijumpai di Riau dan sebagian menjadi ciri khas dari Riau. Pembelajaran yang dilakukan mahasiswa dengan memanfaatkan kearifan lokal membuat pembelajaran yang dilakukan menjadi lebih bermakna (Hariyadi, dkk., 2016).

Hasil analisis data pada penelitian ini tercantum pada tabel 1 dan tabel 2 mengenai hasil uji validasi ahli. Tabel 1 menunjukkan hasil validasi ahli terhadap panduan praktikum biokimia II khusus mahasiswa diperoleh persentase sebesar 85,93\% pada kategori sangat layak. Tabel 2 menunjukkan hasil validasi ahli terhadap panduan praktikum biokimia II khusus dosen/asisten diperoleh persentase sebesar $88,84 \%$ pada kategori sangat layak. Setelah melakukan revisi dan menambahkan saran-saran validator, panduan praktikum diujicobakan pada kelompok kecil. Tabel 3 menunjukkan hasil uji coba keterbacaan oleh kelompok kecil diperoleh persentase sebesar 85,94 pada kategori sangat layak.

Hasil uji validasi panduan praktikum khusus mahasiswa pada setiap aspek memiliki nilai di atas $80 \%$. Hal ini menunjukkan bahwa panduan praktikum khusus mahasiswa telah memenuhi aspek yang diharapkan. Panduan praktikum biokimia II khusus mahasiswa telah tersusun secara sistematis. Penyajian tahapan prosedur praktikum pada setiap materinya mengikuti tahapan inkuiri terbimbing dengan pendekatan kearifan lokal Riau. Langkah-langkah tahapan inkuiri terbimbing bertujuan untuk mempermudah mahasiswa dalam menemukan konsep. Pendekatan kearifan lokal Riau merupakan pemanfaatan kekayaan alam sekitar Riau seperti ikan, tepung, minyak dan bahan lainnya sebagai sampel saat praktikum. Dengan proses tersebut, mahasiswa tidak hanya mendapatkan ilmu, melainkan mendapatkan keterampilan untuk mengeksplorasi seorang diri ilmu tersebut dari sekitarnya (Zukmadini, dkk., 2018). Dengan adanya panduan praktikum biokimia II berbasis inkuiri terbimbing dengan pendekatan kearifan lokal Riau diharapkan mahasiswa dapat mengembangkan diri dan dapat berperan secara langsung pada pertumbuhan pengetahuan serta teknologi. Oleh karenanya, panduan praktikum biokimia II khusus mahasiswa ini sangat layak digunakan dalam perkuliahan praktikum biokimia II. 
Panduan praktikum khusus dosen/asisten dimaksudkan untuk mempermudah dosen/asisten dalam menjalankan tugas pada saat perkuliahan praktikum biokimia II. Pada panduan praktikum khusus dosen/asisten terdapat silabus, SAP, kunci jawaban pertanyaan dan sistem penilaian perkuliahan praktikum biokimia II. Hasil uji validasi panduan praktikum khusus dosen/asisten pada setiap aspek memiliki nilai rata-rata diatas $80 \%$. Hal ini menunjukkan bahwa panduan praktikum khusus dosen/asisten telah memenuhi aspek yang diharapkan, maka panduan praktikum biokimia II khusus dosen/asisten sangat layak digunakan dalam perkuliahan praktikum biokimia II. Uji coba kelompok kecil ini menitikberatkan pada kelengkapan panduan praktikum, kebahasaan dan kemudahan dalam memahami petunjuk. Berdasarkan tabel 3 dapat diamati bahwa panduan praktikum ekspansi produk memiliki nilai rata-rata skor 4,29 dengan rata-rata persentase sebesar $85,94 \%$. Nilai ini menunjukkan bahwa panduan praktikum biokimia II berbasis inkuiri terbimbing dengan pendekatan kearifan lokal Riau yang dikembangkan sangat layak digunakan pada perkuliahan praktikum biokimia II.

Tujuan dikembangkannya panduan praktikum biokimia II berbasis inkuiri terbimbing yaitu agar mahasiswa dapat mengonstruksi pengetahuan sendiri. Peranan pengajar hanya sebagai motivator, moderator dan fasilitator bagi mahasiswa dalam mengonstruksi pengetahuannya. Pembelajaran yang berbasis kearifan lokal merupakan suatu kegiatan yang dilakukan dengan mengaitkan lingkungan tempat tinggal mahasiswa atau terkait dengan situasi nyata dunia sekitar mahasiswa. Pembelajaran yang demikian akan menjadi lebih bermakna (Zuchdi, dkk., 2012). Menurut Syaban, dkk. (2016) pada pembelajaran sains terpadu mahasiswa dapat merasakan pengalaman langsung, sehingga mahasiswa memperoleh kecakapan untuk menyerap, menyimpan, dan menggunakan pemikiran yang telah dipelajarinya.

Dengan dikembangkannya panduan praktikum biokimia II berbasis inkuiri terbimbing dengan pendekatan kearifan lokal Riau dapat menjadi solusi program studi Pendidikan Kimia FKIP UR dalam menerapkan pembelajaran terintegrasi. Terwujudnya tujuan program studi pendidikan kimia FKIP UR menjadi pusat penelitian dan pengembangan pendidikan kimia, serta mampu menciptakan tamatan yang bermutu serta berguna untuk masyarakat Riau pada khususnya dan Indonesia pada umumnya pada tahun 2020 (Tim Penyusun Kurikulum Program Studi Pendidikan Kimia, 2014).

\section{SIMPULAN}

Berdasarkan penjabaran di atas, maka dapat disimpulkan bahwa panduan praktikum biokimia II khusus mahasiswa dan panduan praktikum biokimia II khusus dosen/asisten sangat layak digunakan pada perkuliahan praktikum biokimia II. Berdasarkan penjabaran yang diperoleh, maka disarankan untuk mengembangkan bahan ajar untuk mewujudkan tujuan program studi pendidikan kimia FKIP UR.

\section{DAFTAR RUJUKAN}

Anggraini, A. (2016). Pengembangan Petunjuk Praktikum Biologi pada Materi Jamur dengan Pola Pemberdayaan Berpikir melalui Pertanyaan (Studi Kasus di Kelas X.3 SMA Muhammadiyah 1 Metro Tahun Pelajaran (2013/2014). Jurnal Pendidikan Biologi Universitas Muhammadiyah Metro, 7, 73-80.

Arends, R. I. (2012). Learning to teach (9th Editio). New York: The McGraw-Hill Companies, Inc.

Arifin, U. F., Hadisaputro, S., \& Susilaningsih, E. (2015). Pengembangan Lembar Kerja Praktikum Siswa Terintegrasi Guided Inquiry untuk Keterampilan Proses Sains. Chemistry in Education, 4(1), 54-60.

Arikunto, S. (2012). Dasar-Dasar Evaluasi Pendidikan Edisi 2. Jakarta: Bumi Aksara.

Hariyadi, D., Ibrohim, I., \& Rahayu, S. (2016). Pengaruh Model Pembelajaran Inkuiri Terbimbing Berbasis Lingkungan terhadap Keterampilan Proses dan Penguasaan Konsep IPA Siswa Kelas VII pada Materi Ekosistem. Jurnal Pendidikan: Teori, Penelitian, Dan Pengembangan, 1(8), 1567-1574.

Mukhtar, Z., Emiliya, R., \& Silaban, R. (2015). Pengembangan Penuntun Praktikum Model Discovery dan Project Based Learning pada Pembelajaran Asam dan Basa di SMA Kelas XI. Jurnal Pendidikan Tabularasa, 12(3), https://doi.org/10.24114/jt.v12i3.3256

Merdekawati, K. (2012). Menumbuhkan Keunggulan Bangsa Melalui Pendidikan Kimia Berbasis Local Genius. Yogyakarta: Universitas Islam Indonesia.

Piaget, J., \& Duckworth, E. (1970). Genetic Epistemology. American Behavioral Scientist, 13(3), 459-480.

Prince, M. J., \& Felder, R. M. (2006). Inductive Teaching and Learning Methods: Definitions, Comparisons, and Research Bases. Journal of Engineering Education, 95(2), 123-138.

Qing, Z., Jing, G., \& Yan, W. (2010). Promoting Preservice Teachers' Critical Thinking Skills by Inquiry-Based Chemical Experiment. Procedia-Social and Behavioral Sciences, 2(2), 4597-4603.

Sa'ud, S. U. (2008). Inovasi Pendidikan. Bandung: Penerbit Alfabeta.

Suastra, I. W. (2010). Model Pembelajaran Sains Berbasis Budaya Lokal untuk Mengembangkan Potensi Dasar Sains dan Nilai Kearifan Lokal di SMP. Jurnal Pendidikan dan Pengajaran, 43(1).

Syaban, M. F., \& Wilujeng, I. (2016). Pengembangan SSP Zat dan Energi Berbasis Keunggulan Lokal untuk Meningkatkan Literasi Sains dan Kepedulian Lingkungan. Jurnal Inovasi Pendidikan IPA, 2(1), 66-75. https://doi.org/10.21831/jipi.v2i1.8369

Tampubolon, E. H. M. (2015). Inovasi Model Bahan Ajar Unsur-Unsur Kimia Berbasis Kearifan Lokal Fakultas Keguruan dan Ilmu Pendidikan Universitas HKBP Nommensen Medan. Jurnal Suluh Pendidikan FKIP-UHN, 3(1), 100-108. 
Thiagarajan, S. (1974). Instructional Development for Training Teachers of Exceptional Children: A Sourcebook.

Tim Penyusun Kurikulum Program Studi Pendidikan Kimia. (2014). Kurikulum Berbasis Kompetensi Mengacuh Pada KKNI Tahun 2014. Pekanbaru: Program Studi Pendidikan Kimia.

Yani, A. F. S. (2015). Pengembangan Penuntun Praktikum Kimia SMA Kelas XI pada Materi Hidrolisis Garam Sesuai Model Pembelajaran Penemuan dan Berbasis Proyek. Tesis tidak diterbitkan. UNIMED, Medan.

Zakiah, Z., Silalahi, A., \& Muchtar, Z. (2015). Pengembangan Penuntun Praktikum Tipe Discovery dan Tipe Project Based Learning pada Pembelajaran Elektrolit dan Non Elektrolit di SMA. Jurnal Pendidikan Kimia, 7(1), 83-94.

Zuchdi, D., Prasetya, Z. K., \& Masruri, M. S. (2012). Model Pendidikan Karakter Terintegrasi Dalam Pembelajaran dan Pengembangan Kultur Sekolah. Yogyakarta: UNY Press.

Zukmadini, A. Y., Karyadi, B., \& Trisnawati, W. (2018). Strategi Pembelajaran Biologi Berbasis Lingkungan Melalui Kombinasi Pembelajaran Indoor dan Outdoor Sebagai Upaya Meningkatkan Keterampilan Proses Siswa SMA. Prosiding Seminar Nasional Pendidikan Biologi, 1(1), 148-155. 